Оригінальні наукові роботи

(c) Колесник М.О., Дріянська В.Є., Величко М.Б., Драннік Г.М., Непомнящий В.М., Савченко В.С., Гайсенюк Ф. 3., 2016

УДК: 611-018.74:616.611-002.2-036.12

М.О. КОЛЕСНИК, В.Є. ДРІЯНСЬКА, М.Б. ВЕЛИЧКО, Г.М. ДРАННІК, В. М. НЕПОМНЯЩИЙ, В.С. САВЧЕНКО, Ф. З. ГАЙСЕНЮК

СУДИННИЙ ЕНДОТЕЛІАЛЬНИЙ ФАКТОР РОСТУ ТА НLА-ФЕНОТИП У ХВОРИХ НА ХРОНІЧНИЙ ГЛОМЕРУЛОНЕФРИТ

\author{
M. KOLESNYK, V. DRIYANSKA, M. VELYCHKO, G. DRANNIK, \\ V. NEPOMNYASCHIY, V. SAVCHENKO, F. GAISENIUK
}

\title{
VASCULAR ENDOTHELIAL GROWTH FACTOR AND HLA-PHENOTYPE IN PATIENTS WITH CHRONIC GLOMERULONEPHRITIS
}

Державна установа «Інститут нефрології Національної академії медичних наук України»

$$
\text { SI «Institute of Nephrology NAMS of Ukraine» }
$$

Ключевые слова: сосудистый эндотелиальный фактор роста, антигены гистосовместимости, гломерулонефрит, нефротический синдром

Key words: VEGF (vascular endothelial growth factor), HLA (human leucocyte antigens), glomerulonephritis, nephrotic syndrom.

Резюме. Цель работы - установить особенности сывороточных уровней VEGF у больных хроническим гломерулонефритом с нефротическим синдромом и ассоциативные связи с HLA для определения дополнительных предикторов течения заболевания.

Материалы и методы: Исследованы распределение НLA-антигенов у больных хроническим гломерулонефритом с нефротическим синдромом (534 пациента) путем типирования лимфоцитов методом Терасаки и сывороточные уровни VEGF (80 больных) методом ИФА. Диагноз подтвержден морфологически с использованием нефробиопсии.

Результаты. Показано распределение $H L A-A, B$ антигенов в 2 группах больных с разным фоновым уровнем VEGF в сыворотке крови. Выявлены ассоциации некоторых антигенов гистосовместимости с высокими уровнями в крови сосудистого эндотелиального фактора роста.

Заключение. Установлено, что у больных хроническим гломерулонефритом с нефротическим синдромом и фенотипом HLA-A9, A10 (25+26) и В8 высокий уровень VEGF и отсутствие его снижения при лечении глюкокортикоидами (особенно при А10 (25+26) и B8) ассоциируется со стероидорезистентностью.

Summary. It was to determine associations the serum levels of VEGF and with HLA in patients with chronic glomerulonephritis and nephrotic syndrome (CGN, NS).

Materials and methods. There was studied the serum levels of VEGF (80 patients) by ELIZA and HLA-antigens distribution in the CGN, NS patients (534) by typing the lymphocytes with the aid of standard microlymphocytotoxic test (Terasaki's test). The diagnosis was confirmed morphologically using by nephrobiopsy.

Results. The distribution of HLA-A,B antigens of the 2 group patients having the CGN, NS with various serum levels of VEGF is shown. Associations of some HLA-antigens and high levels of vascular endothelial growth factor in blood were noted.

Conclusion. High serum level VEGF and HLA-A9, A10(25+26) and B8 in CGN, NS patients associated with steroidoresistence.

ВСТУП. Сучасні дані свідчать про важливу роль ендотеліальної дисфункції (ЕД) в патогенезі хронічної хвороби нирок: гломерулонефриту 3 нефротичним синдромом (ХХН: ГН, НС), яка разом з імунологічними механізмами призводить до ушкодження судин нирок та прогресування хвороби [1, 9, 12, 19].

Порушення регуляції або стимуляції процесу ангіогенезу без функціональних потреб організму

\section{Дріянська Вікторія Свгенівна} kirin@inephrology.kiev.ua призводять до посилення ангіогенної форми ЕД, тому важливу роль відіграють фактори, що продукуються в ендотелії, серед яких привертає увагу судиний ендотеліальний фактор росту VEGF (vascular endothelial growth factor). VEGF впливає не тільки на ендотелій, але й на багато інших процесів - формування лімфатичних судин, пригнічення дендритних клітин, необхідних для клітинної імунної відповіді, стимулювання хемотаксису моноцитів, зниження токсичності ліпопротеїдів низької щільності по відношенню до ендотелію $[2,13,14]$; цікавими є роботи щодо важливої ролі VEGF в патогенезі артеріальної гіпертензії (АГ) [9, $16,18]$. 
В нирці VEGF експресується подоцитами, стимулює проліферацію/регенерацію ендотелію, що призводить до відновлення гломерулярних та перитубулярних капілярів та зниження площі гломерулярного та інтерстиціонального фіброзу. Описано достовірне підвищення рівнів VEGF у хворих на АГ при розвитку нефропатії. Виявлено пряму кореляцію між мікроальбумінурією і рівнем екскреції 3 сечею молекулярних медіаторів РАІ-1, ТФР-в1, а також рівнем VEGF і колагену IV типу, що вказує на прогресування ендотеліальної дисфункції і активацію механізмів фіброгенезу, які є ланками процесів ремоделювання мікросудин нирки при гіпертонічній нефропатії $[12,15]$. Іншими авторами також встановлено, що екскреція з сечею VEGF у хворих на ХГН була достовірно вища ніж у здорових, і в динаміці прогресування тубулоінтерстиціальних змін показник VEGF знижується, що також свідчить про участь VEGF у патогенезі ХГН [1].

Для нашого дослідження дуже важливим є той факт, що ген VEGF локалізований в 6-й хромосомі, так само як і гени головного комплексу гістосумісності HLA (human leucocyte antigens) [14], однією з головних фізіологічних функцій яких $€$ регуляція імунної відповіді.

Рядом досліджень показано, шо наявність того чи іншого фенотипу системи HLA визначає схильність до багатьох патологій, в тому числі захворювань нирок та варіантів гломерулонефриту, відповідної реакції на лікування $[4,7,8]$. В той же час, у формуванні імунної відповіді окрім генів головного комплексу гістосумісності (HLA) важливе місце займають поліморфні гени цитокінів, що розміщені на 5 та 6 хромосомах людини), і актуальними $€$ дослідження цих взаємозв'язків [6, 10].

МЕТА РОБОТИ: визначення особливостей сироваткових рівнів VEGF і асоціативних зв'язків 3 HLA як додаткових предикторів перебігу ХГН, НC.

МАТЕРІАЛ ТА МЕТОДИ ДОСЛІДЖЕННЯ. Рівні VEGF в сироватці крові 80 хворих на ХГН, НС (XXH I-III ст.) визначали на аналізаторі «SunRise TouchScreen» 3 використанням IФA і тест-систем DRG (США); група порівняння - 25 здорових донорів.

HLA визначали за допомогою стандартного мікролімфоцитотоксичного тесту на планшетах Терасакі з застосуванням спеціальної панелі антиHLA сироваток (20 антигенів локусу A, 31 - В і 9 - DR) у пацієнтів з XXН I-III ст. (264 пацієнта) та V ст. (270 пацієнтів), хворих на ХГН, НС і 350 здорових осіб (група контролю). Достовірність різниці частоти визначення HLA-антигенів, що порівнювалися, оцінювали за допомогою критерію хі-квадрат для таблиць 2 х2.

Всім пацієнтам було проведене клінічне і лабораторне обстеження, результатом якого стало підтвердження діагнозу XXH I-III ст. первинного гломерулонефриту з нефротичним синдромом. Лабораторні дослідження проводились згідно стандартних методик в клінічній лабораторії інституту.
Хворі, які були обстежені у рамках даного дослідження, спостерігались у клініці, отримуючи загально прийняте необхідне щодо їх стану лікування.

Всім хворим з НС та морфологічно встановленим типом гломерулонефриту була призначена імунотропна терапія згідно Протоколів лікування хворих на ХГН з НС і рекомендацій KDIGO 2012.

Протягом початкових 8-12 тижнів раз на 2 тижні оцінювали рівень добової протеїнурії, протеїнемії, функцію нирок. При відсутності зниження протеїнурії до субнефротичного рівня між 12-16 тиж. лікування пацієнт визначався гормонрезистентним. Ефективність лікування для всіх хворих на ХГН визначалась як повна клініко-лабораторна ремісія (ПКЛР) при зниженні добової протеїнурії $<200$ мг/д, часткова клініко-лабораторна ремісія (ЧКЛР) при зниженні добової протеїнурії <3,5 г/ добу. Якщо при проведенні лікування у пацієнтів не відмічалось зниження протеїнурії <3,5 г/д, або відмічалось погіршення функції нирок - перебіг захворювання вважали торпідним. Це слугувало показанням до перегляду програми лікування.

Результати обстеження хворих на XXH V ст., в анамнезі яких був ХГН з НС, оцінювали ретроспективно.

РЕЗУЛЬТАТИ ТА ОБГОВОРЕННЯ. У ХВОрих на ХГН, НС виявлено підвищення в сироватці крові середніх рівнів VEGF - 236,6 [194; 294,3] порівняно з 96,4 [16; 3,5] пкг/мл у групі контролю $(\mathrm{p}<0,001)$; у пацієнтів 3 досягнутою клініко-лабораторною ремісією (КЛР) під впливом імунотропної терапії відбувалось його достовірне зниження $(\mathrm{p}<0,001)$ до норми $(146,1 \pm 14,3$ пг/мл), на відміну від осіб з ТП $(278,0 \pm 34,1$ пг/мл, $\mathrm{p}=0,897)$. При досягненні КЛР рівень показника був > 220 пг/мл у $15 \pm 3,6 \%$ хворих, а у разі відсутності ефекту ліку-

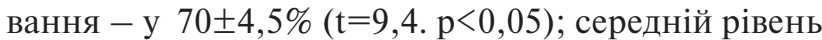
VEGF при ТП з персистуванням НС достовірно перевищував як норму $(\mathrm{p}=0,006)$, так і показники при КЛР $(p=0,012)$. Тому, можна вважати високий рівень VEGF в крові, що не знижується під впливом терапії, прогнозонегативним маркером.

Зважаючи на це, представляють інтерес отримані дані імуногістохімічних досліджень щодо рівнів експресії VEGF у нирках. VEGF виявлявся в цитоплазмі подоцитів, епітелії проксимальних і дистальних звивистих канальців та сполучних трубочок. Проте рівень подоцитарної експресії VEGF суттєво відрізнявся при непроліферативному і проліферативному гломерулонефриті з НС. Так, середній бал подоцитарної експресії VEGF у контролі, при хворобі мінімальних змін, фокальному сегментарному гломерулосклерозі (поза межами сегментарних змін) та мембранозній нефропатії становив: $2,5 \pm 0,6,2,3 \pm 0,5,2,0 \pm 0,4$ та 2,3 $\pm 0,5$ відповідно, проти $1,6 \pm 0,7$ та $1,5 \pm 0,9$ при $\operatorname{IgA-нефропатії~та~лю-~}$ пус-нефриті відповідно $(\mathrm{p}=0,005)$. Спостерігалась негативна кореляція між експресією VEGF і ступенем гломерулярного ушкодження (ендокапілярної 
проліферації) при проліферативному гломерулонефриті ( $\tau=-0,40 ; p=0,03)$.

Для аналізу асоціативних зв'язків 3 HLAфенотипом хворі були розподілені наступним чином - в 1 гр з найбільш високою продукцією цього цитокіну за рівнем у крові (>220 пкг/мл, що перевищує норму норму більше ніж в 2 рази) - увійшло 43 хворих проти 37 з більш низьким рівнем (2 гр). Різниця показника VEGF між групами достовірна - відповідно, 258 [237,3; 295] проти 163,4 [120,0; 192,3] (p<0,001).

Антиген А9 не зустрічався у 2 групі, тому різниця між групами достовірна (табл. 1). Аналіз рівнів VEGF у носіїв антигену також виявив достовірно вищий середній показник порівняно з хворими без

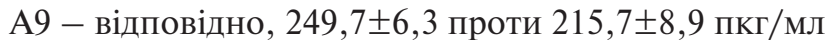
$(\mathrm{p}=0,003)$. Хоча частота А9 в 1 гр. не відрізнялась від групи контролю та всіх протипованих хворих на XXН I-III ст. $(\mathrm{n}=264)$, можна було б вважати, що незалежно від асоціації з хворобою носії HLA-A9 здатні до високої продукції VEGF. Але, якщо розглядати А9 як антиген, складовою якого є А23 i $\mathrm{A} 24$, які обумовлюють високий відносний ризик ХГН, НС [5], то виявлені асоціації між наявністю A9 в фенотипі та високим рівнем VEGF саме у наших пацієнтів є важливими.

Частота антигену A10 $(25+26)$ в 1 гр майже в 2 рази перевищувала показник у 2 групі $(\mathrm{p}=0,011)$ i достовірно відрізнялась від всіх хворих на ХГН (табл. 1) та здорових $(\mathrm{p}<0,001)$, так само як і його складової HLA-A25, оскільки ії частота у разі найбільш високого рівня VEGF перевищувала таку у групі порівняння в 5 разів порівняно з групою контролю $(p=0,008)$ (табл. 1$)$.

Таблиия 1

Частота HLA-аг локусу А у хворих на ХГН, НС з найбільш високими рівнями VEGF в крові (1 гр) в порівнянні з такою у всіх пацієнтів (3) та хворих з менш високою (2 гр) продукцією цитокіну

\begin{tabular}{|c|c|c|c|c|c|c|c|c|}
\hline HLA-A & $\begin{array}{c}\text { частота } \\
\text { аг (\%)y } \\
\text { здорових } \\
\text { n=350 }\end{array}$ & $\begin{array}{c}\text { частота } \\
\text { аг (\%) y } \\
\text { хворих } \\
\text { n=264 }\end{array}$ & RR (P 3-2) & $\begin{array}{c}\text { частота } \\
\text { аг (\%) } \\
\text { в } 1 \text { гр } \\
\text { n=43 }\end{array}$ & P 5-3 & $\begin{array}{c}\text { частота } \\
\text { аг (\%) } \\
\text { в } 2 \text { гр } \\
\text { n=37 }\end{array}$ & P 7-3 & P 5-7 \\
\hline 1 & 2 & 3 & 4 & 5 & 6 & 7 & 8 & 9 \\
\hline A1 & 28,0 & 25,7 & 0,89 & 18,6 & $\mathrm{p}=0,402$ & 10,8 & $\mathrm{p}=0,992$ & $\mathrm{p}=0,505$ \\
\hline A3 & 17,1 & 12,5 & 0,69 & 2,3 & $\mathrm{p}=0,044$ & 24,3 & $\mathrm{p}=0,118$ & $\mathrm{p}=0,007$ \\
\hline A9 & 20,0 & 11,3 & $0,51(\mathrm{P}=0,005)$ & 16,3 & $\mathrm{p}=0,897$ & 0 & $\mathrm{p}=0,009$ & $\mathrm{p}=0,014$ \\
\hline A $10(25+26)$ & 17,1 & 14,0 & 0,80 & 58,1 & $\mathrm{p}<0,001$ & 28,0 & $\mathrm{p}=0,100$ & $\mathrm{p}=0,011$ \\
\hline A19 $(30+33)$ & 4,8 & 4,1 & 0,86 & 9,3 & $\mathrm{p}=0,100$ & 24,3 & $\mathrm{p}=0,064$ & $\mathrm{p}=0,133$ \\
\hline A23 & 2,3 & 7,5 & $3,48(p=0,004)$ & 7,0 & $\mathrm{p}=0,742$ & 19,0 & $\mathrm{p}=0,068$ & $\mathrm{p}=0,204$ \\
\hline A24 & 6,3 & 13,2 & $2,27(\mathrm{P}=0,005)^{\wedge}$ & 21,0 & $\mathrm{p}=0,328$ & 14,0 & $\mathrm{p}=0,803$ & $\mathrm{p}=0,564$ \\
\hline $\mathrm{A} 25$ & 9,1 & 7,9 & 0,86 & 28,0 & $\mathrm{p}=0,002$ & 5,4 & $\mathrm{p}=0,928$ & $\mathrm{p}=0,015$ \\
\hline A28 & 8,0 & 15,1 & $2,05(\mathrm{P}=0,009)^{\wedge}$ & 25,6 & $\mathrm{p}=0,191$ & 29,7 & $\mathrm{p}=0,083$ & $\mathrm{p}=0,873$ \\
\hline B8 & 13,4 & 28,7 & $2,56(\mathrm{p}<0,001)^{\wedge}$ & 39,5 & $\mathrm{p}=0,402$ & 16,2 & $\mathrm{p}=0,140$ & $\mathrm{p}=0,039$ \\
\hline B38 & 0,9 & 4,9 & $5,97(p=0,004)$ & 7,0 & $\mathrm{p}=0,764$ & 5,4 & $\mathrm{p}=0,857$ & $\mathrm{p}=0,865$ \\
\hline B41 & 0,9 & 4,5 & $5,5(\mathrm{p}=0,007)$ & 11,6 & $\mathrm{p}=0,181$ & 10,8 & $\mathrm{p}=0,290$ & $\mathrm{p}=0,811$ \\
\hline B44 & 0,3 & 6,8 & $24,32(\mathrm{p}<0,001)$ & 14,0 & $\mathrm{p}=0,216$ & 29,7 & $\mathrm{p}<0,001$ & $\mathrm{p}=0,151$ \\
\hline
\end{tabular}

Розподіл хворих на групи за наявністю А10 (25+26) (I - 35 хв.) та без нього (II - 45 хв) продемонстрував достовірне підвищення середніх рівнів VEGF у носіїв антигену А10 - відповідно: 246,8 [157,4; 268,3] проти 204,1 [171,4; 242,8] $(\mathrm{p}=0,042)$. У пацієнтів, в фенотипі яких зустрічався А25 як складова антигену A10, рівень VEGF був також більш висо-

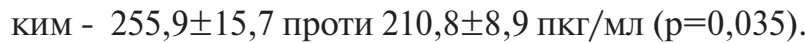

За нашими даними, наявність в HLA антигенів A10, В41 та В51, відноситься до найбільш прогнозонегативних, асоціюючих з розвитком XXН V ст. (табл. 2). Протекторами виступають А19, 24, 26, 34 i B12, $16(\mathrm{p}=0,003)$.

Виявлену асоціацію прогнозонегативного для функції нирок A10 (25+26) з більш високою продукцією судинного фактору росту в периферичній крові пацієнтів можна вважати одним із важливих для перебігу ХГН факторів.
HLA-A3 рідше виявлявся при високих рівнях VEGF (p=0,007), відносний рівень хворих з А3 в цій групі достовірно відрізняється від показника для всіх хворих на ХГН (табл. 1). Рівень цього медіатора у носіїв А3 (I гр) достовірно нижче, ніж у інших хворих (II гр) - 175,6 [114,9; 213] проти 231,2 $[179,7 ; 263,2](p=0,017)$, тобто антиген А3 виступає додатковим прогностичним маркером менш високого рівню судинного фактору росту в крові, що $є$ позитивним для хворих на ХГН, НС.

За локусом HLA-B виявлено достовірно більшу частоту наявності В8 в фенотипі хворих з найвищими рівнями VEGF (1 гр) - майже у 40\% порівняно з 16\% у пацієнтів 2 гр. $(\mathrm{p}=0,039)$ (табл. 1), а також з 13\% у групі контролю $(\mathrm{p}=0,001)$. Розподіл хворих на групи залежно від того, чи є антиген В8 складовою фенотипу, показав, що рівень VEGF у осіб з цим антигеном (I гр) достовірно вище, ніж у інших хворих (II гр) $244,7 \pm 11,5$ проти $210,7 \pm 10,1$ пкг/мл $(\mathrm{p}=0,031)$. 
Частота розподілу НLA-A, В антигенів у хворих на XXH V ст., ГН з НС, відносний та атрибутивний ризик розвитку захворювання

\begin{tabular}{|c|c|c|c|c|c|c|}
\hline \multicolumn{7}{|c|}{ ХXН V ст., ГН, НС } \\
\hline \multicolumn{7}{|c|}{ ЛОКУС А } \\
\hline HLA-A & $\begin{array}{c}\text { n-aг } \\
\text { контроль } \\
(\mathrm{N}=350)\end{array}$ & $\begin{array}{c}\text { n-aГ хворi } \\
(N=270)\end{array}$ & $\begin{array}{c}\text { частота } \\
\text { аг (\%) y } \\
\text { здорових }\end{array}$ & $\begin{array}{l}\text { частота аг } \\
\text { (\%) у хворих }\end{array}$ & $\mathbf{R R} / \mathbf{p}$ & $\sigma$ \\
\hline A1 & 98 & 55 & 28,0 & 20,4 & 0,66 & $-0,56$ \\
\hline $\mathrm{A} 2$ & 173 & 132 & 49,4 & 48,9 & 0,98 & $-0,02$ \\
\hline A3 & 60 & 60 & 17,1 & 22,2 & 1,38 & 0,06 \\
\hline A9 & 70 & 71 & 20,0 & 26,3 & 1,43 & 0,08 \\
\hline A10 & 60 & 93 & 17,1 & 34,4 & $\begin{array}{c}2,54 / \\
\mathrm{p}<0,001\end{array}$ & 0,21 \\
\hline A11 & 57 & 34 & 16,3 & 12,6 & 0,74 & $-0,05$ \\
\hline A19 & 17 & 0 & 4,8 & 0 & $\mathrm{P}<0,001$ & \\
\hline A23 & 8 & 7 & 2,3 & 2,6 & 1,11 & 0,003 \\
\hline A24 & 22 & 2 & 6,3 & 0,7 & $\begin{array}{c}0,11 / \\
\mathrm{p}<0,001\end{array}$ & $-0,06$ \\
\hline A25 & 32 & 14 & 9,1 & 5,2 & 0,54 & $-0,04$ \\
\hline A26 & 22 & 5 & 6,3 & 1,8 & $\begin{array}{c}0,28 / \\
\mathrm{p}=0,008\end{array}$ & $-0,05$ \\
\hline A28 & 28 & 26 & 7,9 & 9,6 & 1,23 & 0,02 \\
\hline A34 & 6 & 0 & 1,7 & 0 & $\mathrm{P}=0,042$ & \\
\hline B5 & 56 & 48 & 16,0 & 17,2 & 1,09 & 0,01 \\
\hline B7 & 73 & 56 & 20,9 & 20,7 & 0,99 & $-0,001$ \\
\hline $\mathrm{B} 8$ & 47 & 32 & 13,4 & 11,9 & 0,87 & $-0,02$ \\
\hline B12 & 73 & 31 & 20,9 & 11,5 & $\begin{array}{c}0,49 / \\
\mathrm{p}=0,002\end{array}$ & $-0,26$ \\
\hline $\mathrm{B} 13$ & 61 & 44 & 17,4 & 16,3 & 0,92 & $-0,01$ \\
\hline B14 & 25 & 34 & 7,1 & 12,6 & 1,87 & 0,06 \\
\hline B15 & 34 & 16 & 9,7 & 5,9 & 0,59 & $-0,04$ \\
\hline B16 & 33 & 9 & 9,4 & 3,3 & $\begin{array}{c}0,33 / \\
\mathrm{p}=0,003\end{array}$ & $-0,07$ \\
\hline B17 & 50 & 32 & 14,3 & 11,9 & 0,81 & $-0,03$ \\
\hline $\mathrm{B} 18$ & 29 & 35 & 8,3 & 12,9 & 1,65 & 0,05 \\
\hline B21 & 20 & 23 & 5,7 & 8,5 & 1,54 & 0,03 \\
\hline B22 & 18 & 8 & 5,1 & 2,9 & 0,56 & $-0,03$ \\
\hline B27 & 29 & 29 & 8,3 & 10,7 & 1,33 & 0,03 \\
\hline B35 & 60 & 31 & 17,1 & 11,5 & 0,63 & $-0,07$ \\
\hline B41 & 3 & 22 & 0,9 & 8,2 & $\begin{array}{c}10,27 / \\
\mathrm{p}<0,001\end{array}$ & 0,07 \\
\hline B51 & 5 & 25 & 1,4 & 9,3 & $\begin{array}{c}7,04 / \\
p<0,001\end{array}$ & 0,08 \\
\hline
\end{tabular}

При аналізі інших цитокінів нами виявлено, що HLA-B8 асоціює також з високим рівнем прозапального МСР-1 та більш низьким, ніж у інших хворих, протизапального ІЛ-4. Так, частота антигену В8 в групі з його найвищими рівнями (17 хворих) складає $71 \%$ порівняно з $27 \%$ у інших 22 об- стежених пацієнтів ( $\mathrm{p}=0,021)$, так само як і з $13,4 \%$ у здорових $(\mathrm{p}<0,001) .3$ іншого боку, його частота в групі найбільш високих рівнів протизапального ІЛ-4 (40 хворих) достовірно нижча, ніж у решти 32 обстежених за цим інтерлейкіном - відповідно, 30,0 проти $58,7 \%(\mathrm{p}=0,026)$. 
Отримані дані дуже цікаві, оскільки антиген B8, за нашими даними, обумовлює не тільки відносний ризик захворювання на ХГН, НС (продемонстрований також Rashid H.U. et al. [17]), але й стероїдрезистентність (табл. 3). А на думку деяких дослідників, гломерулонефрит може мати спадкове походження, обумовлене саме В8 [11].

Таблиия 3

Вiдносний (RR) та атрибутивний ризик $(\sigma)$ в групах стероїдчутливих (CЧ) та -резистентних (CP) хворих на ХГН, НС, за даними розподілу НLA-A, В антигенів

\begin{tabular}{|c|c|c|c|c|c|c|}
\hline HLA-A, B & $\begin{array}{c}\text { n-aг контроль } \\
\text { n=350 }\end{array}$ & $\begin{array}{c}\text { n-aГ } \\
\text { CЧ Xвopi } \\
(64) \\
\end{array}$ & $\begin{array}{c}\text { Частота Аг } \\
\text { (\%)у здорових }\end{array}$ & $\begin{array}{c}\text { Частота Аг (\%) } \\
\text { у СЧ хворих }\end{array}$ & $\mathrm{RR} / \mathrm{p}$ & $\sigma$ \\
\hline A11 & 57 & 20 & 16,3 & 31,25 & $\begin{array}{c}2,34 / \\
\mathrm{p}=0,014\end{array}$ & 0,18 \\
\hline A23 & 8 & 8 & 2,3 & 12,5 & $\begin{array}{c}6,10 / \\
p=0,005\end{array}$ & 0,11 \\
\hline A28 & 28 & 23 & 8,0 & 35,9 & $\begin{array}{c}6,48 / \\
p<0,001\end{array}$ & 0,3 \\
\hline A30 & 2 & 4 & 0,6 & 6,2 & $\begin{array}{c}11,61 / \\
\mathrm{p}=0,026\end{array}$ & 0,06 \\
\hline B8 & 47 & 20 & 13,4 & 31,2 & $\begin{array}{c}2,90 \\
\mathrm{P}=0,002\end{array}$ & 0,21 \\
\hline B14 & 25 & 17 & 7,1 & 26,6 & $\begin{array}{c}4,70 / \\
\mathrm{p}<0,001\end{array}$ & 0,21 \\
\hline B38 & 3 & 4 & 0,8 & 6,2 & $\begin{array}{c}7,70 / \\
\mathrm{P}=0,046\end{array}$ & 0,05 \\
\hline B41 & 3 & 8 & 0,8 & 12,5 & $\begin{array}{c}16,53 / \\
p<0,001\end{array}$ & 0,12 \\
\hline B44 & 1 & 11 & 0,3 & 17,2 & $\begin{array}{c}49,98 / \\
p<0,001\end{array}$ & 0,12 \\
\hline B51 & 5 & 5 & 1,4 & 7,8 & $\begin{array}{c}5,80 / \\
\mathrm{P}=0,036\end{array}$ & 0,06 \\
\hline A28 & 28 & 9 & 8,0 & 23,7 & $\begin{array}{c}3,58 / \\
p=0,018\end{array}$ & 0,17 \\
\hline A30 & 2 & 3 & 0,6 & 7,9 & $\begin{array}{c}14,96 / \\
\mathrm{P}=0,041\end{array}$ & 0,07 \\
\hline B8 & 47 & 10 & 13,40 & 38,5 & $\begin{array}{c}4,03 / \\
\mathrm{P}=0,008\end{array}$ & 0,29 \\
\hline B41 & 3 & 5 & 0,8 & 13,2 & $\begin{array}{c}17,53 / \\
\mathrm{P}=0,003\end{array}$ & 0,10 \\
\hline B44 & 1 & 9 & 0,3 & 23,7 & $\begin{array}{l}108,56 / \\
\mathrm{P}<0,001\end{array}$ & 0,24 \\
\hline
\end{tabular}

Таким чином, у хворих на ХГН, НС високий рівень в крові VEGF, який не знижується під впливом терапії, є предиктором резистентності до неї та ТП захворювання. Найбільш висока продукція VEGF відмічена у хворих з антигенами HLA-A9 (в складі якого обумовлюючі атрибутивний ризик ХГН А23 та А24), А 10 (25+26) (що асоціює з розвитком ХХН) і В8 (обумовлює відносний ризик ХГН і торпідний перебіг через гормонрезистентність). Антигени, що обумовлюють ризик захворювання на ХГН та його етіологічну фракцію - A23, 24, 28 - не виявили асоціацій з VEGF (хоча перші два є складовими А9, у якого виявлена асоціація з високим рівнем цього медіатора).

ВИСНОВОК. У хворих на ХГН, НС з фенотипом HLA-A9, A10 (25+26) та B8 встановлений досто- вірний зв'язок з навністю високого рівня VEGF, а відсутність його зниження під впливом лікування глюкокортикоїдами (особливо за наявності А10 (25+26) та В8) асоціюється зі стероїдорезистентністю.

\section{ЛІТЕРАТУРА:}

1. Бобкова И. Н. Клиническое значение определения в моче маркеров ендотелиальной дисфункции и факторов ангиогенеза в оценке тубулоинтерстиционального фиброза при хроническом гломерулонефрите / И. Н. Бобкова, Л. В. Козловская, А. С. Рамеева, В. А. Варшавский, Е. П. Голицина. - Терапевтический архив. 2007. - № 6. - С. 10-15.

2. Гавриленко Т. И. Сосудистый эндотелиальный фактор роста в клинике внутренних заболева- 
ний и его патогенетическое значение / Т. И. Гавриленко, Н. А. Рыжкова, А. Н. Пархоменко // Український кардіологічний журнал. - 2011. - № 4. - С. 87-95.

3. Зарецкая Ю. М. Клиническая иммуногенетика / Ю. М. Зарецкая // М. : Медицина, 1983. - 103 с.

4. Колесник M. О. Асоціації особливостей HLAфенотипу та чутливістю до лікування кортикостероїдами у хворих на хронічний гломерулонефрит з нефротичним синдромом / М. О. Колесник, Г. М. Драннік, В. Є. Дріянська, О. П. Петрина, М. Б. Величко // Український журнал нефрології та діалізу. - 2013. - № 1 (37). - С. 37-45.

5. Колесник M. О. НLA-фенотип у хворих на хронічний гломерулонефрит $з$ нефротичним синдромом / М. О. Колесник [та ін.] // Журнал НАМН України. - 2014. - Т. 20, № 2. - С. 206211.

6. Коненков В. И. Структурные основы и функциональная значимость аллельного полиморфизма генов цитокинов человека и их рецепторов / В. И. Коненков, М. В. Смольникова // Медицинская иммунология. - 2003. - Т. 5, № 1-2. - С. 11-28.

7. Короткова П. Ю. Иммуногенетический анализ вариантов клинического течения и прогноза хронического гломерулонефрита в Западной Сибири / П. Ю. Короткова, М. Ф. Валентик, Е. А. Мовчан, В. С. Максимов [и др.] // Терапевтический архив. - 2006. - № 8. - С. 73 79.

8. Лутай M. I. Імунопатологічні реакції та імуногенетичні чинники при ішемічній хворобі серця / М. І. Лутай, Т. І. Гавриленко, Ж. М. Мінченко [и др.] // Журнал АМН України. - 2010. - Т. 16, № 2. - С. 245-261.

9. Мангилева T. A. Система сосудистого эндотелиального фактора роста и артериальная гипертензия / Т. А. Мангилева // Серце і судини . - № 4. - 2012. - С. 107-115.

10. Сенников C. В. Роль авльтернативного сплайсинга генов цитокинов в формировании полиморфной структуры цитокиновой сети / C. В. Сенников, А. Н. Силков, В. А. Козлов // Медицинская иммунология. - 2001. - Т. 3, № 3. - С. 389-400.
11. Шестаков A. Е. Исследование ассоциации ряда генов-кандидатов с хроническим гломерулонефритом : автореф. дис. ... к. б. н. : 03. 02. 07. - Генетика / А. Е. Шестаков ; Гос. НИИ генетики и селекции пром. микроорганизмов. - М., 2006. -28 c.

12. Ayerden E. F. The relationship between vascular endothelial growth factor (VEGF) and microalbuminuria in patients with essential hypertension / E. F. Ayerden, E. Haksun, D.B. Ulver et al. // Intern. Med. - 2008. - 47(17). 1511-1516

13. Coultas L. Endothelial cells and VEGF in vascular development / L. Coultas, K. Chawengsaksophak, J. Rossant // Nature. - 2005. - 438, № 7070. - P. 937-945.

14. Ferrara N. Vascular endothelial growth factor / N. Ferrara // Arterioscler. Thromb.Vasc. Biol. - 2009. - 29. - 789-791.

15. Kubisz $P$. Circulating vascular endothelial growth factor in the normo- and/or microalbuminuric patients with type 2 diabetes mellitus / P. Kubisz, P. Chudэ, J. Stasko et al. // Act. Diabetol. - 2010. - Vol. 47 (2). - P. 119-124.

16. Palmirotta R. VEGF-A gene promoter polymorphisms and microvascular complications in patients with essential hypertension / R. Palmirotta, P. Ferroni, G. Ludovici et al. // Clin. Biochem. 2010. - 43(13-14). - 1090-1095.

17. Rashid H. U. The association of HLA and other genetic markers with glomerulonephritis / H. U. Rashid [et al.] // Human Genetics. - 1983. - 63. - P. 38-44.

18. Siervo M. Angiogenesis and biomarkers of cardiovascular risk in adults with metabolic syndrome / M. Siervo, D. Ruggiero, R. Sorice et al. // J. Intern. Med. - 2010. - 268 (4). - 338-47.

19. Watts G. F. Vascular function of the peripheral circulation in patients with nephrosis / G. F. Watts, S. Herrmann, G. K. Dogra et al. // Kidney Int. 2001. - 60. - P. 182-189.

Надійшла до редакції 27.06.2016 Прийнята до друку 02.08.2016 